Throughout the pageantry, the wealth and splendour of display of personal adornment, dress, and equipment vividly described in, for example, the dispatches of the correspondent of The Times in the issues of February 23 and 24, there is apparent an all-embracing current of mystic symbolism which endues every act, every movement and every attendant circumstance with the significance of worship, and of recognition of the spiritual influence which centres in and emanates from the person of the reincarnated head of the Tibetan spiritual and political hierarchy. It is this, and not the fact that such ceremonial has not been enacted in Lhasa for the space of sixty years, which animated the crowds through which the Dalai Lama was carried in his golden palanquin to the Potala, and on the following day added a solemn meaning to the blessings of a child conferred on the elders of church and State and later sanctified what was otherwise an unseemly scramble for the Dalai Lama's food as a re-enactment of the ancient ritual of sharing in the flesh of the sacrificial victim.

\section{Relics of the Buddha}

BudDhisw of another order, but nevertheless of a closely related world of thought, appears in the announcement that Buddha relics of exceptional sanctity, discovered in Central India nearly ninety years ago and since in private possession in England, will now return to the East. They have been given to a Buddhist Temple in Ceylon by Mrs. Leslie Smith and Mrs. Winifred Burrows, granddaughters of General F. C. Maisey, by whom they were discovered when with Sir Alexander Cunningham he was investigating the numerous Buddhist monuments around Bhilsa in 1851. The discovery, as described in The Times of February 27, consisted of a relic casket-a small crystal tope, with terrace, plinth, hemispherical dome, square pedestal and a double pinnacle, this last forming the stopper of a small perpendicular shaft. This casket has been dated at about 350 B.c. The relic ehamber at the bottom of the shaft contained minute pieces of bone, the whole being enclosed in a red earthenware box, which also contained other pieces of bone, and a series of the seven precious things usually accompanying the relics of an eminent person, namely, thin round pieces of gold, a bead of garnet, a crystal bead, two beads of pale greenish crystal, and some minute fragments of pearl.

The casket is now in the India Section of the Victoria and Albert Museum, South Kensington; but a cast and photographs have been supplied by the authorities in order that a replica may be made in Ceylon by native craftsmen. The relics and the seven precious things, which were retained by General Maisey when he presented most of the antiquities to the Museum, have now been enclosed in a carved silver tope from Ceylon for their conveyance to the island.

\section{Sutton Hoo Burial a Cenotaph?}

IN an account of the excavation of the Sutton Hoo ship-burial and of the associated antiquities delivered before the Society of Antiquaries of London on
February 22 (see Nature, Feb. 10, p. 231), Mr. C. W Phillips referred to the remarkable feature of the deposit that it did not accompany a body. The explanation which he put forward on certain grounds was that the mound and its contents as a whole had the character of a cenotaph for a great man whose body could not be recovered, possibly through being lost at sea. One suggestion which has been offered, namely that it may have been a measure of insurance on the part of a recently Christianized pagan in an endeavour to make the best of both alternatives, is perhaps not to be taken seriously. Nevertheless survival of a pagan ritual, even in such an essential rite as burial, cannot be ruled out entirely; and it receives a certain amount of support from the archaic character of the ship, of which some further account was given.

The excavation of the ship was under the direction of Lieutenant-Commander J. K. D. Hutchinson of the Science Museum, South Kensington. It proved to be a remarkable vessel in the form of an open barge, clinker-built, keel-less, and propelled by at least thirtyeight oars. It was described as a development of a type already known to archaeologists, and, it may be supposed, of a type already archaic at the time of its burial. In its character as a royal barge, a comparison was instituted with the position of the royal yacht Victoria and Albert among contemporary shipping. This view would accord with the interpretation of the find which emphasizes its highly ceremonial nature. At the same time it may be recalled that ship models found by the Danish Thule Expedition to Greenland pointed to Norse ships still being in use of which the essential features had remained unchanged for a period of nearly six hundred years.

\section{Cosmic Rays}

THE twenty-fourth Guthrie Lecture of the Physical Society was delivered by Prof. P. M. S. Blackett on February 26. He took as his subject "Cosmic Rays : Recent Developments". He said that the most important discovery of recent years in the field of cosmic rays was the realization that the hard or penetrating component of the rays consists of particles of a new type, called mesotrons. This new particle has a mass intermediate between that of the electron and the proton and possesses the peculiar property of being spontaneously unstable. Its average life when at rest is about one millionth of a second, but when moving fast it lives longer-thus giving a nice verification of Einstein's principle of relativity.

The rays incident on the earth's atmosphere are of very great energy. Recent work shows that some of the rays have an energy certainly as high as one thousand million million volts. This is an astonishingly great energy, and it is probably not the limit. It is quite likely that rays exist with energy as high as a million million million volts or even more. Particles of such great energy have very peculiar properties. Instead of producing a narrow track of ionization a fraction of a millimetre broad like normal atomic tracks, they make a track many metres broad. This is deduced from relativity theory, but has not 
yet been verified experimentally. Great interest is attached to the 'spectrum' of the rays incident on the earth's atmosphere, since they should give some light on a possible origin for the rays. It is rather remarkable to find that the spectrum of the rays can be represented roughly by a simple power law over a range of energy of above a million to one. More precisely, the number of rays with energy greater than some given value is roughly inversely proportional to the square of the energy, over the energy range from a thousand million to a thousand million million volts. It can scarcely be doubted that this remarkable law must have some profound, but at present unknown, cosmological significance.

\section{Fuel in Science and Practice}

THE monthly periodical Fuel in Science and Practice has completed eighteen volumes since it was launched as a supplement to the well-known mining journal Colliery Guardian. It was established on the initiative of the Coal Research Club in order to provide a medium of communication for those interested in the scientific study of fuel, and coal in particular. It was the first journal of its kind in the English language and has proved very suecessful, the success being doubtless due in a large measure to the efforts of its first editor, the late Prof. R. V. Wheeler. The first number of the nineteenth volume has now appeared under the editorship of Dr. R. Lessing, who has been associated with the venture since its inception. This, it may be taken, will ensure continuity of policy. It will continue to aim at providing a clearing-house for the results of investigations and a bridge between the science and practice of fuel technology.

The Institute of Fuel has decided to adopt Fuel as its research journal for the benefit of its members who wish to be kept informed of the results of recent investigations into coal and other combustibles. The Coal Research Club, assisted by an editorial commit. tee, will continue to direct its policy and ensure the maintenance of its old and successful traditions. It seems probable that the importance of fuel technology for some years to come will ensure a prosperous future for this journal. At the same time, it is pertinent to recall the unsatisfactory state of the documentation of science. While it appears relatively easy to publish journals containing interesting articles, the thankless task of publishing systematic abstracts is a growing burden the support of which meets steady reluctance.

\section{Coal-Gas and Fuel Research at Leeds}

Prow. D. T. A. Townend, who succeeded Prof. J. W. Cobb as head of the Department of Coal-gas and Fuel Industries and Livesey professor in the University of Leeds, has now issued his first report, covering the session 1938-39, to his Advisory Committee. He takes an opportunity therein to pay a tribute to the late Prof. Smithells, who died during the term under review and who was a member of the Committee from the time of its formation. To him also was due, more than to any other man, the formation of the Fuel Department in the University and, a few years later, the establishment of the Livesey chair by subscriptions from the gas industry.

In the body of the report, Prof. Townend reviews in turn the varied activities of his department, which has developed in severăal directions, not only fuel and gas engineering, but also the cognate subjects of refractory materials and metallurgy, in both of which teaching and research have made much headway. A post-graduate diploma in fuel and refractory materials has been instituted along similar lines to those already given in gas engineering and in fuel and metallurgy. The first opportunity will be taken to give a more systematic course in chemical engineering, which is, in effect, so largely the subject of the departmental teaching. Research continues to be supported by the gas industry and the Iron and Steel Institute. Prof. Townend is continuing work on flame, which had engaged him in London, and independent research work carried out by the staff and students continues to be a marked feature of the departmental activity.

\section{Modern Colour Printing}

IN the Electrical Review of February 2, an illustrated description is given of some of the new equipment installed by Geo. C. Caster and Co., Ltd., commercial and colour printers, who recently transferred their works to Cromwell Road, Peterborough. In accordance with modern practice the factory has been set out on a single floor, with a planned layout for the speedy handling of work and an uninterrupted continuity of production. There is no shafting, and individual direct electric drive is employed on all machines. One of the large high-speed letterpress machines is a two-revolution Miehle capable of a maximum output of 3,000 sheets, 25 in. by 40 in., per hour. Another large two-revolution machine takes bigger sheets ( 30 in. by 40 in.) and can print 2,300 sheets per hour. For small sheets up to $13 \frac{1}{2}$ in. by 20 in. vertical Miehle machines are brought into service. These'are specially suitable for high-class colour printing. A maximum of 4,500 prints an hour can be handled by each machine.

The use of a general lighting system of high intensity throughout the factory makes local lighting unnecessary (except under the machine boards). In the composing room an illumination intensity of $35 \mathrm{ft}$.-candles at the working plane is obtained with Benjamin reflectors, which are also used in the binding department to provide $10 \mathrm{ft}$.-candles. To facilitate the matching of ink colours, daylight reflectors have been installed in the machine department to give $14 \mathrm{ft}$.-candles.

\section{The Achromatic Lens}

THe contributions made to Lychnos during the last two years by Drs. N. V. E. Nordenmark and J. Nordstrom dealing with the invention of the achromatic lens and the part played by $\mathrm{S}$. Klingenstierna, professor of mathematics at the University of Uppsala, in the process, have been issued as a pamphlet by Almquist and Wiksells, Uppsala, with an English summary. Many of the original documents bearing 